DOI: https://doi.org/10.47405/mjssh.v6i1.608

\begin{tabular}{|c|c|}
\hline 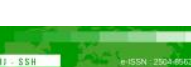 & Malaysian Journal of Social Sciences and Humanities (MJSSH) \\
\hline Malaysian Journal of & Volume 6, Issue 1, January 2021 \\
\hline (MJ-ssH) & e-ISSN : 2504-8562 \\
\hline & $\begin{array}{l}\text { Journal home page: } \\
\text { www.msocialsciences.com }\end{array}$ \\
\hline
\end{tabular}

\title{
Kemiskinan Adalah Satu Fenomena Multidimensi: Suatu Pemerhatian Awal
}

\author{
Parthiban S.Gopal1 , Muhammad AlNaufal Abdul Rahman', Nor Malina Malek', ParamjitSingh \\ Jamir Singh1, Law Chee Hong ${ }^{1}$ \\ ${ }^{1}$ Pusat Pengajian Sains Kemasyarakatan, Universiti Sains Malaysia (USM) \\ Correspondence: Parthiban S.Gopal (parthi@usm.my)
}

\begin{abstract}
Abstrak
Kemiskinan merupakan satu fenomena yang dialami oleh seseorang individu tanpa kerelaan dan kehendak mereka. Kemiskinan boleh dikategorikan kepada dua jenis iaitu material dan bukan material. Miskin material terdiri daripada miskin pendapatan dan bukan pendapatan iaitu pendidikan, akses kepada kesihatan, pekerjaan dan kemudahan awam. Manakala miskin bukan material ialah berkait berkenaan ciri-ciri sahsiah seperti emosi, psikologi dan rohani. Kesemua keadaan yang berlaku ini menyebabkan seseorang yang miskin mengalami kesukaran untuk keluar dari situasi kemiskinan sekiranya tiada tindakan yang dilakukan oleh pihak bertanggungjawab. Pengukuran kemiskinan adalah langkah awal dalam mengenal pasti golongan miskin. Terdapat dua jenis iaitu pengukuran kemiskinan undimensi yang melihat kemiskinan dari sudut pendapatan sahaja dan pengukuran kemiskinan multidimensi yang melihat pada aspek holistik serta kemanusiaan. Terdapat banyak kelemahan pada pengukuran unidimensi kerana ia hanya mengukur kemiskinan dari perspektif pendapatan sahaja. Hal ini sudah tentulah tidak komprehensif dalam pengenalpastian golongan yang miskin. Oleh itu pengukuran kemiskinan multidimensi akan diterokai bagi memahami dengan lebih lanjut seperti perbezaannya dengan pengukuran unidimensi dan mengapakah Indeks Kemiskinan Multidimensi (IKM) adalah pengukur kemiskinan yang paling sesuai lagi berkesan. Kajian ini menggunakan data sekunder sebagai metodologi kajian. Hasil kajian ini dijangka bukan sahaja boleh mengetahui berapa ramai yang miskin dan peratusannya, malahan kita juga boleh mengetahui dimensi penyumbang utama kepada masalah kemiskinan. Melalui pengukuran ini, sesuatu program atau pemberian insentif dapat disalurkan dengan tepat kepada kumpulan sasaran.
\end{abstract}

Kata kunci: Indeks Kemiskinan Multidimensi (IKM), kemiskinan unidimensi, kemiskinan multidimensi, kemiskinan material dan bukan material

\section{Poverty is a Multidimensional Phenomenon: A Preliminary Observation}

\begin{abstract}
Poverty is a phenomenon experienced by an individual without their consent and will. Poverty can be categorizes into two types namely material and non-material. The material poor consist of poor income and non-income namely education, access to health, employment and public facilities. While the nonmaterial poor are related to personality traits such as emotional, psychological and spritual. All these situations make it difficult for a poor person to get out of poverty if no action is taken by responsible party. Measuring poverty is a first step in identifying the poor. There are two types, namely the measurement of undimensional poverty which sees povery in terms of income only and multidimensional poverty measurement in contrast sees poverty in every aspect of human lives. There
\end{abstract}


are many disadvantages to measuring unidimensional poverty because it only measures individual income. This is certainly not comprehensive in identifying the poor. Therefore, multidimensional poverty measurement will be explored to better understand how it differs from unidimensional measurement and why the Multidimensional Poverty Index (MPI) is the most appropriate measure of poverty. This study uses secondary data as the research methodology.

Keywords: Multidimensional Poverty Index (MPI), unidimensional poverty, multidimensional poverty, material and non-material poor

\section{Pengenalan}

Kemiskinan merupakan kekurangan yang dihadapi oleh seseorang untuk menjalani kehidupan seperti masyarakat yang normal. Kekurangan yang dihadapi oleh individu yang miskin boleh dikenal pasti berdasarkan pendapatan yang tidak mencukupi untuk membeli keperluan asas, tahap pendidikan yang tidak tinggi, perolehan harta ataupun aset kekayaan yang tidak banyak serta masalah kesihatan sedikit sebanyak mengganggu kelangsungan individu untuk hidup dalam keadaan normal. Situasi yang mereka alami ini amatlah sukar untuk mereka keluar dari situasi kemiskinan sekiranya tiada bantuan dan sokongan diberikan kepada mereka. Fenomena kemiskinan sekiranya tidak dibendung akan mempengaruhi secara negatif ke atas ekonomi, politik dan sosial negara (Ghani, 1984).

Jumlah insiden kemiskinan secara global menunjukkan tren yang menurun (United Nation, 2016). Penurunan jumlah kemiskinan dunia ini menunjukkan usaha pembasmian kemiskinan giat dijalankan walaupun terdapat kekangan seperti konflik, kemarau dan bencana alam. Mengikut laporan dari United Nation (2016) jumlah kemiskinan telah menurun dari 36 peratus pada tahun 1990 kepada 16 peratus pada tahun 2010 dibawah 1.90 Dolar sehari (United Nation, 2016). Walaupun laporan Persatuan bangsa-bangsa bersatu (United Nation) tersebut dilihat positif, namun, masih terdapat masalah jurang perbezaan antara kaya dan miskin yang begitu ketara semakin meningkat. Jurang antara kaya dan miskin amatlah membimbangkan kerana ia akan mencetus satu kitaran ganas kemiskinan (vicious cycle of poverty). Kitaran ganas kemiskinan merupakan teori yang dinyatakan oleh Nurkse sebagai penindasan yang mengekalkan negara miskin dalam keadaan miskin (Rohima et al., 2013). Mengikut Nurkse (Rohima et al., 2013) seseorang individu yang terperangkap dalam kitaran ganas kemiskinan ini akan diwarisi oleh generasi seterusnya tanpa harapan untuk menghapuskan perangkap kemiskinan. Oleh itu disinilah peranan pihak berkuasa serta pertubuhan bukan kerajaan untuk membantu isi rumah yang miskin keluar dari kitaran ganas kemiskinan dengan melaksanakan program pembasmian kemiskinan seperti menyediakan akses pendidikan, peluang pekerjaan, kemudahan infrastruktur, akses kesihatan dan taraf hidup yang baik seperti menyediakan rumah yang sempurna memainkan peranan yang penting. Malah peranan isi rumah dalam memperbaiki taraf hidup juga ditekankan agar golongan miskin ini mempunyai sikap tidak bergantung pada pihak lain untuk keluar dari kemiskinan (Jamil \& Hadijah, 2014). Dalam hal ini, perkara paling penting dalam langkah pertama untuk membasmi kemiskinan adalah bagaimana ia mentafsirkan kemiskinan. Hal ini kerana pentafsiran kemiskinan ataupun konsep kemiskinan adalah berbeza mengikut masa dan negara, disebabkan oleh keadaan bencana alam, kemarau, perang dan sebagainya yang berlaku mengikut peredaran masa dan negara yang berbeza menunjukkan definisi yang tidak menentu. Oleh itu pentafsiran kemiskinan yang tidak mengikut peredaran masa dan negara tertentu seterusnya pula tidak dapat menghasilkan pengukuran kemiskinan yang lebih baik dalam mengenal pasti kemiskinan. Sesungguhnya melalui pengukuran yang berkesan, sesuatu program atau pemberian insentif dapat disalurkan dengan tepat kepada kumpulan sasaran.

Penerangan awal yang telah dibincangkan ini mengutamakan aspek dalam pengukuran kemiskinan yang berkaitan dengan pentafsiran kemiskinan dan seterusnya memainkan peranan yang penting dalam pembasmian kemiskinan. Perbincangan seterusnya akan menekankan perbezaan tafsiran kemiskinan unidimensi dan multidimensi. Malah tafsiran kemiskinan multidimensi akan diteroka dengan lebih lanjut dan diikuti oleh penerangan kepentingan mekanisme pengukuran kemiskinan Indeks Kemiskinan 
Multidimensi yang lebih kontemporari serta komprehensif dibandingkan dengan pengukuran kemiskinan konvensional iaitu unidimensional.

\section{Sorotan Literatur}

\section{Konsep Kemiskinan Unidimensi}

Pendekatan ukuran kemiskinan konvensional yang menggunakan pendekatan pendapatan sering digunakan oleh kebanyakan negara sebagai kaedah untuk mengukur dan memantau kadar kemiskinan. Terdapat dua jenis pengukuran kemiskinan yang menggunakan pendekatan unidimensional (kewangan) iaitu kemiskinan mutlak dan kemiskinan relatif. Kedua-dua jenis kemiskinan ini mengambil kira faktor pendapatan dan kepenggunaan ataupun kesukaran mendapatkan sesuatu item seperti barang aset, bahan basah dan kering serta sebagainya. Kemiskinan mutlak dan kemiskinan relatif merupakan konsep yang lebih menonjol berbanding konsep kemiskinan yang lain kerana ia telah digunakan oleh pelbagai negara sejak diperkenalkan pada pada abad ke-19 oleh Charles Booth (Laderchi, 2000). Konsep kemiskinan ini mula diperkenalkan hasil kajian ke atas golongan miskin di timur London oleh Charles Booth pada tahun 1887. Kemiskinan mutlak bermaksud kekurangan dari segi pendapatan seseorang untuk membeli keperluan asas yang minimum untuk ahli isi rumah manakala bagi kemiskinan relatif pula adalah perbezaan tingkat pendapatan sesuatu kumpulan dengan kumpulan yang lain (Siti \& Roslan, 2011).

Pendekatan pengukuran kemiskinan mutlak ditentukan berdasarkan pendapatan minima Paras Garis Kemiskinan (PGK). Seseorang diklasifikasikan sebagai miskin sekiranya pendapatan di bawah PGK. Ciri-ciri yang ada di dalam PGK boleh mengenal pasti taburan kemiskinan sesuatu kawasan geografi, kumpulan sosioekonomi dan perbezaan antara miskin dan bukan miskin. Kaedah pengukuran kemiskinan PGK mengambil kira jurang pendapatan dan kepenggunaan dalam kalangan miskin dan bukan miskin. Manakala bagi kemiskinan relatif pula mengukur kemiskinan dari segi agihan pendapatan dan ia juga boleh mengenal pasti jurang ekonomi dan sosial antara miskin dan bukan miskin (Ragayah, 2007)

Namun begitu konsep kemiskinan mutlak dan relatif ini merupakan konsep yang sempit kerana ia tidak mengambil kira faktor seperti mudah diancam, pengasingan sosial, ketidakupayaan untuk terus hidup dan sebagainya (Saladin et al., 2011a, 2011b). Menurut Sabina \& Maria (2011) pengukuran kemiskinan berdasarkan pendapatan tidak dapat mengukur faktor kemanusiaan yang dihadapi oleh golongan miskin. Walaupun isi rumah mempunyai gaji minimum yang mencukupi namun keperluan pendidikan, akses bekalan air dan elektrik masih menjadi kekangan dalam kehidupan mereka. Townsend (1979) juga berpendapat kekurangan pendapatan bukanlah aspek utama dalam kemiskinan. Selain daripada faktor pendapatan terdapat faktor yang lain seperti ketidakupayaan, ketersisihan, ketandusan hak asasi, ketiadaan akses terhadap kemudahan, pendidikan dan kesihatan yang menjadi punca kemiskinan (Amartya Sen, 1990). Titik tolak daripada faktor ini, timbulnya tafsiran kemiskinan secara multidimensi yang melihat kemiskinan secara luas berbanding konsep pengukuran unidimensi.

Walaupun pengukuran kemiskinan telah ditambahbaikkan dengan melengkapkan dimensi yang sedia ada namun begitu Amartya Sen (1987) berpendapat kebanyakan kajian empirikal kemiskinan masih menggunakan pengukuran kemiskinan unidimensi atau berteraskan kewangan. Mengikut beliau baik definisi dan pengukuran miskin unidimensi tersebut adalah sangat sempit dan ini boleh memberi masalah dalam memahami isu kemiskinan yang agak subjektif dan abstrak. Justeru fenomena pentafsiran dan pengukuran kemiskinan perlu dibuat secara berasingan berdasarkan miskin unidimensi dan miskin multidimensi (Fusco, 2003).

\section{Kepentingan Konsep Kemiskinan Multidimensi}

Kita memerlukan sistem yang mampu mengukur keperitan hidup rakyat secara tepat, supaya dasardasar yang dihasilkan berdasarkan ukuran ini benar-benar dapat membantu mereka yang paling memerlukan dengan cara yang tersasar (Nurul Izzah, 2020). Justeru, kemiskinan perlu dilihat dari segi 
multidimensi supaya fenomena kemiskinan dapat difahami dari sudut yang lebih menyeluruh. Alkire dan Foster yang telah memperkenalkan pengukuran kemiskinan Indeks Kemiskinan Multidimensi pada tahun 2010 telah berjaya memantapkan usaha Mahbub ul haq dan Amarthay Sen yang menjadi pelopor dalam penentuan kosep kemiskinan multidimensi (Poverty \& Human Development Initiative. 2013). Menurut Alkire et. al. (2014), Indeks Kemiskinan Pelbagai Dimensi (MPI) merupakan pengukuran kemiskinan alternatif yang dapat mengukur kemiskinan dengan lebih tepat berbanding PGK kerana mengambil kira aspek bukan wang. Selain itu, kaedah MPI merupakan pengukuran kemiskinan komprehensif yang dapat membantu pembuat polisi merangka program pembasmian kemiskinan berdasarkan dimensi dan indikator kemiskinan yang dialami oleh individu.

Pada hakikatnya, Indeks Kemiskinan Multidimensi boleh melengkapkan lagi pengukuran kemiskinan unidimensi (Pathiban, 2013). Pengukuran kemiskinan multidimensi mempunyai elemen yang fokus utamanya adalah dalam dimensi manusia. Kelebihannya adalah dapat melihat keupayaan dan mobilisasi kekuatan manusia, menilai semula keberkesanan dalam pembasmian kemiskinan dan memantapkan lagi dalam menyasarkan kemiskinan, miskin terpencil dan dapat membantu dalam membentuk program pembasmian kemiskinan yang efektif (Alkire \& Santos, 2010). Pengukuran Indeks Kemiskinan Multidimensi akan membantu pembuat dasar supaya pelaksanaan program pembasmian kemiskinan adalah berpusatkan kemanusiaan. Menurut Parthiban (2013) definisi operasional dalam kemiskinan multidimensi mempunyai dua bentuk iaitu dimensi material dan bukan material. Dimensi material ialah seseorang yang mempunyai kekurangan dari segi pendapatan ataupun kadar kepenggunaan harian dan bukan pendapatan seperti pendidikan, kemudahan awam, pekerjaan dan kemudahan kesihatan manakala bagi dimensi bukan material adalah memfokuskan pada aspek sahsiah kemanusiaan seperti faktor emosi, psikologi dan kerohanian(spiritual). Gambaran yang lebih jelas seperti tertera di gambar rajah 1 di bawah berkenaan kemiskinan multidimensi.

\section{Rajah 1: Kemiskinan Multidimensi}

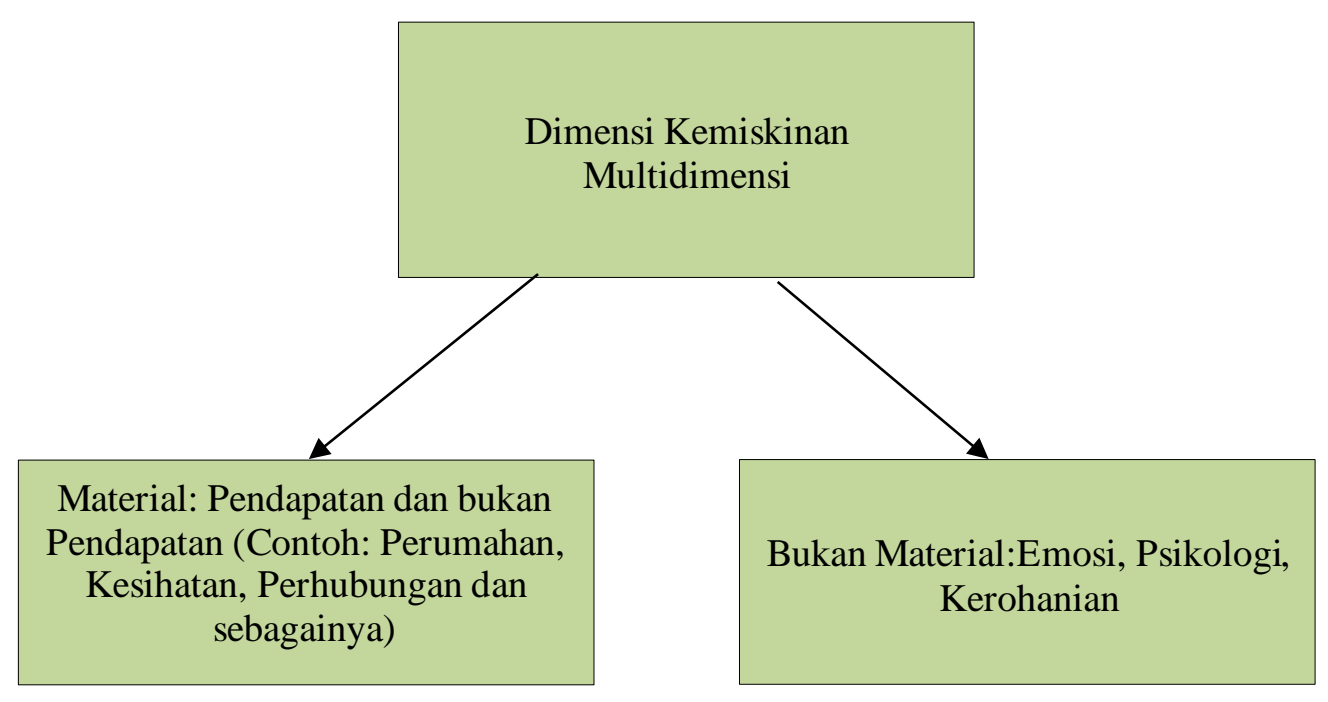

Sumber: Parthiban (2013)

Oleh itu fenomena kemiskinan multidimensi akan memantapkan lagi pendefinisian dalam isu kemiskinan dan dapat mengenal pasti masalah yang dilalui oleh golongan miskin secara komprehensif (Deepa et al., 1999). Kesukaran dalam mengukur kemiskinan telah menjadi perdebatan oleh para akademik di seluruh dunia sejak Paras Garis Kemiskinan (PGK) diperkenalkan. Walaupun pada akhir abad ke dua puluh timbulnya konsep baru dalam mendefinisikan kemiskinan dengan mewajarkan aspek kemanusiaan sebagai teras penting dalam pengukuran kemiskinan namun, pakar pembuat polisi masih mengekalkan pengukuran kemiskinan unidimensi (Michail, 2020). Penggunaan pengukuran kemiskinan berasaskan pendapatan telah menjadi kebiasaan dan asas dalam merangka polisi negara. Oleh itu penekanan pada pengukuran kemiskinan dalam aspek kemanusiaan oleh Amartya Sen perlu dalam pengukuran kemiskinan kerana kemiskinan perlu dilihat menjangkau pendapatan ataupun perolehan kekayaan. Sen menyatakan definisi kemiskinan adalah kompleks dan perlu mengambil kira 
pelbagai ciri dan keadaan masyarakat (Conconi et al., 2017). Perkara asas seperti makanan, tempat tinggal, kesihatan, pendidikan diperlukan untuk membantu dalam memapankan lagi kesejahteraan manusia untuk terus hidup (Watson \& Derrill, 2014). Kesejahteraan manusia yang bergantung pada keupayaan seseorang perlu diambil kira juga dalam pentafsiran dan pengukuran kemiskinan supaya dapat melakukan aktiviti seharian secara lancar, sihat dan bukannya pada jumlah pegangan aset atau material semata-mata (Sen, 1985). Sekiranya manusia mengalami kekangan dalam mengakses perkara asas tersebut maka mereka jatuh dalam kancah kemiskinan.

Fokus harus diberikan pada usaha untuk menjadikan pengukuran kemiskinan multidimensi sebagai pengukur rasmi di Malaysia. Kelebihan yang terletak pada pengukuran kemiskinan multidimensi ini boleh membaiki kelemahan pada pendekatan paras garis kemiskinan dengan mengutamakan aspek kemanusiaan berbanding pendapatan. Aspek pendapatan tidak ditolak dalam pengukuran kemiskinan tetapi bertujuan untuk dimantapkan lagi. Lantas, fenomena kemiskinan yang berbentuk multidimensi menjadi penting dan relevan di Malaysia dalam merangka satu pengukuran yang sesuai terhadap mekanisme pembasmian kemiskinan.

Program pembasmian kemiskinan telah pun dilancarkan oleh pemerintah Malaysia sejak awal pasca kemerdekaan lagi. Sejak Dasar Ekonomi Baru (DEB) dilancarkan pada tahun 1970 jumlah kemiskinan telah menurun dari 49.3\% ke 5.6\% pada tahun 2019 (Jabatan Perangkaan Malaysia, 2020). Pada tahun 2016 jumlah kemiskinan berdasarkan Paras Garis Kemiskinan adalah sebanyak 0.4\% tetapi telah melonjak naik ke 5.6\% untuk tahun 2019 kerana Jabatan Statistik Malaysia telah melakukan perubahan pada paras garis kemiskinan yang asalnya adalah sebanyak RM 980 ke RM2208 berdasarkan metodologi PGK 2019 yang baharu (Jabatan Perangkaan Malaysia, 2020). Namun begitu, angka yang rendah dan yang berubah-ubah itu mengelirukan dan masih kurang tepat walaupun penambahbaikan PGK telah dilakukan berdasarkan metodologi PGK 2019. Sistem pengukuran kemiskinan Malaysia yang dikritik oleh Pelapor Khas PBB Berhubung Kemiskinan Tegar dan Hak Asasi Manusia, Philip Alston pada tahun 2019 (masih relevan walaupun ada penambahbaikan PGK berdasarkan tahun 2019), yang menyatakan bahawa IKM yang direkodkan terlalu rendah $(0.86 \%)$ dan tidak dapat dipercayai kerana kebergantungan sistem tersebut kepada ukuran kemiskinan yang masih berdasarkan pendapatan (Nurul Izzah, 2020).

Walaupun Malaysia telah menurunkan jumlah golongan miskin namun miskin pencil masih wujud dalam kalangan rakyat Malaysia. Punca utamanya bertitik-tolak daripada kebergantungan pada pengukuran kemiskinan unidimensi yang tidak efektif dalam membasmi kemiskinan kerana fenomena kemiskinan pada realitinya adalah berbentuk multidimensi (Yunus, 2007).

Sejak akhir ini sealiran dengan perubahan yang berlaku di serata dunia, Malaysia turut menekankan pentingnya pengukuran kemiskinan multidimensi. Malah, Rancangan Malaysia ke-11 sebenarnya sudah pun memperkenalkan Indeks Kemiskinan Multidimensi (IKM) dimana telah di bentuk dan dinyatakan dalam kajian separuh penggal sebagai satu sebagai pelengkap kepada PGK (Unit Perancang Ekonomi, 2018). Sistem pengukuran yang sebahagiannya dibangunkan PBB ini tidak hanya menekankan pendapatan semata-mata, tetapi ia juga mengambil kira ketersisihan dari pelbagai aspek lain termasuk akses kepada kesihatan, pendidikan dan taraf hidup untuk mengukur kadar kemiskinan secara lebih menyeluruh. Menggunakan sistem pengiraan ini, Malaysia telah mencatat kejadian kemiskinan multidimensi serendah 0.86 peratus setakat 2016. IKM menggunakan data dari Survei Pendapatan Isi Rumah dan Kemudahan Asas (HIS \& BA) untuk mengukur isi rumah yang miskin (Jabatan Perangkaan Malaysia, 2020). Indeks Kemiskinan Multidimensi berfungsi dengan mengambil kira jumlah isi rumah yang miskin multidimensi dalam populasi dan jumlah ketersisihan yang dialami oleh sesebuah isi rumah. Model yang terdapat di dalam Indeks Kemiskinan Multidimensi mempunyai 3 dimensi utama dan 10 indikator. Indeks Kemiskinan Multidimensi memperuntukkan wajaran pada setiap dimensi dan indikator masing-masing. Berdasarkan Jadual 1 dibawah indikator kesihatan dan pendidikan wajaran bagi setiap indikator diberi sebanyak 1/6 manakala bagi dimensi taraf hidup pula setiap indikator diberi sebanyak 1/18. Seseorang akan berisiko untuk jatuh miskin multidimensi sekiranya nilai wajaran adalah kurang satu pertiga (1/3) daripada 10 indikator. 
Jadual 1: Dimensi, indikator, batas ketersisihan dan wajaran IKM

\begin{tabular}{|c|c|c|c|}
\hline $\begin{array}{l}\text { Dimensi } \\
\text { Kemiskinan }\end{array}$ & Indikator & $\begin{array}{l}\text { Kekurangan yang dihadapi oleh } \\
\text { isirumah miskin }\end{array}$ & Wajaran \\
\hline \multirow[t]{2}{*}{ Kesihatan } & Nutrisi & $\begin{array}{l}\text { Orang dewasa di bawah } 70 \text { tahun atau } \\
\text { kanak-kanak kekurangan zat makanan }\end{array}$ & $1 / 6$ \\
\hline & $\begin{array}{l}\text { Kematian } \\
\text { kanak-kanak }\end{array}$ & $\begin{array}{l}\text { Sebelum kajian survei dilakukan lagi ada } \\
\text { kanak-kanak yang meninggal dalam tempoh } \\
\text { lima tahun }\end{array}$ & $1 / 6$ \\
\hline \multirow[t]{2}{*}{ Pendidikan } & $\begin{array}{l}\text { Tahun } \\
\text { Persekolahan }\end{array}$ & $\begin{array}{l}\text { Tiada isi rumah yang berumur } 10 \text { tahun ke } \\
\text { atas menamatkan persekolahan untuk } \\
\text { tempoh enam tahun ke atas }\end{array}$ & $1 / 6$ \\
\hline & $\begin{array}{l}\text { Kehadiran } \\
\text { Ke Sekolah }\end{array}$ & $\begin{array}{l}\text { Kanak-kanak yang tidak hadir ke sekolah } \\
\text { untuk tempoh } 8 \text { tahun persekolahan }\end{array}$ & $1 / 6$ \\
\hline \multirow[t]{6}{*}{ Taraf Hidup } & $\begin{array}{l}\text { Bahan bakar untuk } \\
\text { memasak }\end{array}$ & $\begin{array}{l}\text { Isi rumah menggunakan bahan bakar dari } \\
\text { arang kayu, batu, kayu dan najis. }\end{array}$ & $1 / 18$ \\
\hline & Sanitasi & $\begin{array}{l}\text { Kemudahan tandas yang tidak dibaikpulih } \\
\text { ataupun berkongsi dengan penduduk } \\
\text { setempat. }\end{array}$ & $1 / 18$ \\
\hline & Bekalan Air & $\begin{array}{l}\text { Isi rumah kesukaran dalam mendapatkan } \\
\text { bekalan air bersih seperti terpaksa berulang } \\
\text { alik ke tempat sumber air jarak perjalanan } \\
\text { sekurang-kurangnya } 30 \text { minit. }\end{array}$ & $1 / 18$ \\
\hline & Elektrik & Isi rumah tiada akses bekalan elektrik & $1 / 18$ \\
\hline & Perumahan & $\begin{array}{l}\text { Bumbung,dinding, lantai sekurang- } \\
\text { kurangnya salah satu adalah diperbuat dari } \\
\text { bahan semula jadi }\end{array}$ & $1 / 18$ \\
\hline & Aset & $\begin{array}{l}\text { Isi rumah tidak mempunyai lebih dari satu } \\
\text { aset seperti radio, komputer, basikal, } \\
\text { motorsikal dan sebagainya. }\end{array}$ & $1 / 18$ \\
\hline
\end{tabular}

Sumber: Alkire and Jahan (2018)

Walaubagaimanpun, model IKM tersebut masih belum digunakan sebagai penanda aras dalam penggubalan dasar serta program mekanisme pelaksanaan pembasmian kemiskinan. Sebaliknya mekanisme pembasmian di Malaysia pada umumnya masih bersandarkan unsur unidimensi (pendapatan) PGK. Hal ini terbukti apabila banyak kajian kemiskinan di Malaysia masih menggunakan kajian pengukuran kemiskinan berdasarkan unidimensi untuk menentukan kesejahteraan golongan miskin (Parthiban, 2018). Di samping, sebagaimana yang dinyatakan di perenggan atas, sistem pengukuran kemiskinan Malaysia secara am unidimensional(PGK) dan secara khusus multidimensional secara khusus tersebut dikritik oleh Philip Alston, yang menyatakan bahawa IKM $(0.86 \%)$ yang direkodkan terlalu rendah dan tidak dapat dipercayai kerana kebergantungan sistem tersebut kepada ukuran kemiskinan yang masih berdasarkan pendapatan (Jadual 2).

Jadual 2: Dimensi, indikator, batas ketersisihan dan wajaran IKM (Malaysia)

\begin{tabular}{lllc}
$\begin{array}{l}\text { Dimensi } \\
\text { Kemiskinan }\end{array}$ & Indikator & $\begin{array}{l}\text { Kekurangan yang dihadapi oleh isi } \\
\text { rumah miskin }\end{array}$ & Wajaran \\
\hline Kesihatan & $\begin{array}{l}\text { Akses kepada } \\
\text { kemudahan kesihatan }\end{array}$ & $\begin{array}{l}\text { Jarak kepada kemudahan kesihatan } \\
\text { melebihi 5 km dan tiada kemudahan } \\
\text { klinik kesihatan bergerak disediakan }\end{array}$ & $1 / 8$ \\
\cline { 2 - 5 } & $\begin{array}{l}\text { Akses kepada } \\
\text { bekalan air bersih }\end{array}$ & $\begin{array}{l}\text { Selain daripada bekalan air terawat di } \\
\text { dalam rumah dan paip air awam/ paip } \\
\text { berdiri }\end{array}$ & $1 / 8$ \\
\hline
\end{tabular}


Malaysian Journal of Social Sciences and Humanities (MJSSH), Volume 6, Issue 1, (page 40 - 51), 2021

DOI: https://doi.org/10.47405/mjssh.v6i1.608

\begin{tabular}{|c|c|c|c|}
\hline \multirow[t]{2}{*}{ Pendidikan } & $\begin{array}{l}\text { Bilangan tahun } \\
\text { persekolahan }\end{array}$ & $\begin{array}{l}\text { Semua ahli isi rumah berumur } 17-60 \\
\text { tahun mempunyai kurang daripada } 11 \\
\text { tahun persekolahan }\end{array}$ & $1 / 8$ \\
\hline & $\begin{array}{l}\text { Kehadiran } \\
\text { ke sekolah }\end{array}$ & $\begin{array}{l}\text { Kanak-kanak antara 6-16 tahun yang } \\
\text { tidak bersekolah }\end{array}$ & $1 / 8$ \\
\hline \multirow[t]{6}{*}{ Taraf Hidup } & $\begin{array}{l}\text { Keadaan } \\
\text { tempat tinggal }\end{array}$ & Usang atau mulai buruk & $1 / 24$ \\
\hline & Bilangan bilik tidur & Lebih 2 ahli isi rumah/bilik & $1 / 24$ \\
\hline & Kemudahan tandas & Selain daripada tandas pam & $1 / 24$ \\
\hline & $\begin{array}{l}\text { Kemudahan kutipan } \\
\text { sampah }\end{array}$ & Tiada kemudahan & $1 / 24$ \\
\hline & Pengangkutan & $\begin{array}{l}\text { Semua ahli isi rumah sama ada tidak } \\
\text { menggunakan pengangkutan } \\
\text { persendirian atau pengangkutan awam }\end{array}$ & $1 / 24$ \\
\hline & $\begin{array}{l}\text { Akses kepada alat } \\
\text { komunikasi asas }\end{array}$ & $\begin{array}{l}\text { Tidak memiliki telefon talian tetap atau } \\
\text { telefon bimbit }\end{array}$ & $1 / 24$ \\
\hline Pendapatan & $\begin{array}{l}\text { Pendapatan Bulanan } \\
\text { Purata Isi rumah }\end{array}$ & Pendapatan Bulanan Purata Isi rumah & $1 / 4$ \\
\hline
\end{tabular}

Sumber: Economic Planning Unit 11 (2020).

Justeru perlu ada usaha yang lebih gigih untuk merealisasikan penggubalan dan pelaksanaan IKM dalam pelaksanaan pembasmian kemiskinan supaya Malaysia turut menjadi relevan bersama perubahan yang berlaku di serata dunia yang kini giat melaksanakan IKM dalam program pelaksanaan pembasmian kemiskinan. Kepentingan IKM tersebut turut ditekankan dalam Matlamat Pembangunan Milinium (2000-2015) dan Maglamat Pembangunan Lestari/Mampan(2016-2030). Begitu juga dengan sistem pengukuran yang sebahagiannya dibangunkan Pertubuhan Bangsa-bangsa Bersatu (PBB) itu tidak hanya menekankan pendapatan semata-mata, tetapi ia juga mengambil kira ketersisihan daripada pelbagai aspek lain termasuk akses kepada kesihatan, pendidikan dan taraf hidup untuk mengukur kadar kemiskinan secara lebih menyeluruh (Nurul Izzah, 2020)

\section{Metod Kajian}

Kajian kualitatif ini menggunakan kaedah kajian perpustakaan untuk mencari maklumat sekunder yang berkaitan dengan pengukuran konsep Kemiskinan multidimensi. Maklumat-maklumat yang diperoleh adalah daripada pelbagai sumber seperti buku, jurnal, dan artikel akhbar serta majalah. Maklumat ini dikumpulkan dan disaring serta dianalisis menggunakan teknik analisis kandungan. Analisis kandungan terhasil apabila pengkaji mempunyai matlamat untuk menjalankan kajian literatur. Ia dimulakan dengan menyediakan latar belakang terhadap kandungan kajian literatur yang hendak dijalankan. Seterusnya pengkaji membaca dan memahami bahan literatur yang diperoleh. Akhirnya, pengkaji mengintegrasikan bahan bacaan tersebut kepada pengetahuan yang dimiliki oleh pengkaji. Justeru, daripada analisis yang dijalankan, pengkaji dapat mengenal pasti kepentingan pengukuran kemiskinan dari perspektif multidimensi yang lebih menjurus ke arah pembangunan holistik dan pemantapan kesejahteraan masyarakat yang tersisih (deprived society) dibandingkan dengan pengukuran kemiskinan unidimensional.

\section{Perbincangan Dapatan Kajian}

Pengukuran IKM berkeupayaan untuk mengukur pelbagai jenis bentuk kemiskinan. Setiap bentuk kemiskinan perlu difahami berdasarkan perspektif multidimensi (Liu \& Xu, 2016). Sebagai contoh masalah kemiskinan luar bandar berpunca dari kekangan untuk mendapatkan keperluan asas seperti 
akses air, pendidikan dan sebagainya. Malah faktor kemiskinan juga adalah disebabkan fenomena yang kompleks dan memerlukan satu bentuk alat pengukuran yang boleh menyasarkan kemiskinan secara tepat dan pelbagai dimensi (Alkire et al., 2017). Fenomena kemiskinan yang pelbagai perlu ditekankan bagi membantu dalam mendefinisikan isu kemiskinan agar pengukuran kemiskinan yang multidimensi dapat dibentuk.

Kajian dari Nadia, Fairuz, \& Rahana (2011) merupakan kajian yang terawal menggunakan IKM di Universiti Teknologi Mara (UiTM) Shah Alam, Malaysia. Kajian ini melihat bagaimana situasi kebajikan pelajar mempengaruhi prestasi akademik dengan menggunakan IKM. Terdapat tiga dimensi digunakan dalam pengukuran ini iaitu pendidikan, kesihatan, dan taraf hidup. Kajian mendapati daripada 200 orang pelajar seramai 185 pelajar iaitu $92.5 \%$ jatuh pada miskin multidimensi. Manakala 13 orang pelajar $6.5 \%$ adalah purata multidimensi miskin dan terakhir seramai 2 orang pelajar $1 \%$ adalah miskin tegar multidimensi. Hasil kajian tersebut memaparkan daripada 200 sampel diperoleh didapati seramai 185 orang pelajar diklasifikasikan sebagai miskin multidimensi.

Kajian seterusnya dilakukan oleh Le, Nguyen, \& Phung (2015) di Vietnam. Dimensi yang digunakan adalah kesihatan, pendidikan, sokongan sosial dan insurans, taraf hidup, penyertaan sosial. Keputusan dari pengukuran IKM menunjukkan penduduk dari etnik minoriti dari kawasan sungai Mekong mengalami kemiskinan multidimensi. Antara dimensi yang tertinggi dihadapi oleh penduduk miskin di kawasan tersebut adalah sokongan sosial dan insurans manakala dimensi yang paling terendah adalah taraf hidup. Kajian ini mendapati kemiskinan telah menurun dalam tempoh 2010 hingga 2012 disebabkan mekanisme IKM yang lebih berkesan dan komprehensif sebagai model pengukuran kemiskinan digunakan dalam mengenal pasti golongan sasaran. Setelah golongkan sasaran dikenal pasti proses pembasmian turut menjadi berkesan (Le \& Phung, 2015).

Hasil kajian ini juga mendapati apabila arus pembangunan giat memacu ke hadapan, masalah sosial di kedua-dua luar bandar dan bandar menjadi fenomena yang serius dan tidak dapat dielakkan. Di antara pelbagai permasalahan sosial yang dialami di luar bandar mahupun di bandar akibat pembangunan yang pesat adalah kemiskinan yang tidak terbatas kepada faktor kekangan pendapatan semata-mata tetapi lebih bersifat multidimensi.

Kemiskinan di luar bandar masih lagi menjadi isu yang penting di kalangan negara-negara mundur dan sedang membangun. Pelbagai faktor yang memberi kesan kepada kemunduran yang berlaku di kawasan luar bandar. Antara faktor utama seperti sektor sosioekonomi, kesihatan dan bentuk muka bumi yang mencabar menyumbang kepada kemiskinan di luar bandar (Campos, Villani, Davis, \& Takagi, 2018). Menurut World Bank (2018) dianggarkan sebanyak 79 peratus penduduk yang miskin menghuni kawasan luar bandar. Antara negara yang mempunyai komposisi penduduk luar bandar yang ramai terletak di benua Afrika sebagai contoh Nigeria negara mempunyai penduduk yang ramai di kawasan luar bandar. Nigeria merupakan negara yang kaya dengan sumber alam dengan populasi iaitu 195.9 juta namun ia mempunyai kadar kemiskinan yang ramai sebanyak 93 juta (Iheonu, \& Urama 2019). Oleh itu faktor kemiskinan multidimensi adalah lebih berkesan dalam menggambarkan kemiskinan secara komprehensif.

Kajian daripada Amao, Ayantoye, \& Fanifosi (2017) dengan menggunakan pengukuran kemiskinan Indeks Kemiskinan Multidimensi terhadap penduduk luar bandar di Nigeria didapati daerah utara timur, utara tengah dan utara barat masing-masing mencatatkan kadar isi rumah miskin $(\mathrm{H})$ sebanyak $82.35 \%, 85.9 \%$ dan $91.0 \%$ manakala bagi jumlah isi rumah miskin $(\mathrm{H})$ di kawasan bandar Nigeria iaitu bahagian selatan dan selatan barat masing-masing mencatatkan kemiskinan sebanyak $68.7 \%$ dan 7.4\%. Indeks Kemiskinan Multidimensi menunjukkan ketersisihan dimensi yang paling tinggi bagi kedua-dua kawasan luar bandar dan bandar adalah taraf hidup sebanyak 59.9\% diikuti oleh pendidikan $14.3 \%$, kesihatan $13.4 \%$ dan aset $12.4 \%$. Oleh itu dimensi yang mempunyai ketersisihan yang bukan sahaja paling tinggi tetapi pelbagai ini perlu diutamakan dalam program membasmi kemiskinan yang berpaksi kepada pelbagai dimensi atau multidimensi.

Selain masalah kemiskinan di luar bandar, kemiskinan di bandar juga boleh berlaku sekiranya masyarakat tempatan tidak beri penempatan yang selesa. Kes seperti ini selalu berlaku pada masyarakat miskin bandar yang menduduki penempatan setinggan. Mereka berisiko tinggi untuk dihalau sekiranya 
tiada tindakan untuk memberi hak penempatan yang adil dan saksama kepada mereka. Fenomena in jelas berlaku di daerah Satolla, Dhaka Bangladesh yang menempatkan penduduk setinggan yang kebanyakannya memiliki jenis rumah yang diperbuat dari lumpur, kayu buluh dan dinding zink. Penduduk setinggan di Satolla tidak mempunyai jaminan hak atas tanah mereka duduki walaupun dimiliki oleh pemerintah (Lutfun, 2020). Kekurangan yang dihadapi oleh penduduk setinggan juga berlaku di daerah lain iaitu sebanyak 65\% dan 64\% penduduk miskin IKM setinggan di Khora bosti dan Hafizpara di Khulna Bangladesh mengalami masalah akses seperti bekalan air, sistem sanitasi, sistem kumbahan, perolehan penempatan sementara dan kurangnya hak untuk mengundi. Manakala kawasan penempatan setinggan di bandar yang sama iaitu Natun Char, Mehtor Potti dan Ispahani mengalami masalah akses pendidikan iaitu jarak jauh dari sekolah dan hospital serta akses pada bekalan air bersih. Jelaslah disini bahawa pengukuran kemiskinan haruslah berkonsepkan multidimensi agar dapat mengenal pasti kadar kemiskinan secara tepat daripada pelbagai perspektif iaitu dari aspek penempatan, hak ke atas tanah, kemudahan pengangkutan, akses pendidikan serta kesihatan dan air yang bersih (Sydunnaher, Islam \& Morshed, 2019).

\section{Kesimpulan}

Pengukuran kaedah kemiskinan multidimensi iaitu ukuran kemiskinan pelbagai dimensi atau ringkasnya IKM, perlu diaplikasikan kerana kelebihannya boleh mengenal pasti golongan yang betulbetul miskin ataupun miskin pencil (pocket of poverty). Banyak kajian yang telah menggunakan Indeks Kemiskinan Multidimensi (IKM) menghasilkan dapatan yang lebih menyeluruh berbanding kajian kes yang menggunakan pengukuran kemiskinan undimensi. Dengan menggunakan pendekatan indeks kemiskinan multidimensi (IKM), ia akan mencerminkan kedua-dua insiden ketersisihan pelbagai dimensi (bilangan penduduk yang mengalami ketersisihan dalam pelbagai aspek kehidupan dalam populasi tertentu) dan intensiti (berapa batas ketersisihan dialami secara purata pada sesuatu masa). Sebaliknya, dengan menggunakan pengukuran pendapatan garis kemiskinan (PGK), iaitu ukuran kemiskinan satu dimensi yang biasa diamalkan (pada masa kini) di Malaysia, kita hanya memperoleh satu nilai yang menunjukkan berapa ramai yang miskin sama ada dalam bentuk peratusan atau nilai mutlaknya. Namun dengan menggunakan kaedah pengukuran indeks kemiskinan pelbagai dimensi atau IKM, kita bukan sahaja dapat mengetahui dimensi penyumbang utama kepada masalah kemiskinan malah sesuatu program atau pemberian insentif pembasmian kemiskinan dapat mengenal pasti penyaluran insentif dengan tepat kepada kumpulan sasaran.

\section{Penghargaan}

Sekalung penghargaan ditujukan kepada Kementerian Pendidikan Malaysia atas pembiayaan Skim Geran Penyelidikan Fundamental (FRGS) bernombor 203.PSOSIAL6711691. Terima kasih kepada Pejabat Pengurusan dan Kreativiti Penyelidikan (RCMO), Universiti Sains Malaysia atas bimbingan semasa proses menjalankan kajian ini.

\section{Rujukan}

Abdul Hakim Abdullah, Ab Aziz Sulaiman \& Wan Ismail Wan Abdullah. (2015). Faktor-faktor yang mempengaruhi motivasi terhadap pembelajaran bahasa Arab. Jurnal Islam dan Masyarakat Kontemporari, 10(2), 104-121.

Alkire, S. and Jahan, S. (2018). The New Global MPI 2018: Aligning with the Sustainable Development Goals', HDRO Occasional Paper, United Nations Development Programme (UNDP).

Alkire, S., Apablaza, M., Chakravarty, S., \& Yalonetzky, G. (2017). Measuring chronic multidimensional poverty. Journal of Policy Modeling, 39(6), 983-1006.

Alkire, S., \& Santos, M.E. (2010). Acute multidimensional poverty: A new index for developing countries. OPHI Working Paper 38. United Kingdom, University of Oxford. 
Amao, J. O., Ayantoye, K., \& Fanifosi, G. E. (2017). An analysis of multidimensional poverty and its determinants in rural Nigeria. Journal of Development and Agricultural Economics, 9(11), 303311.

Amartya Sen.(1999). Development As Freedom. United States: Alfred A. Knopf, Inc.

Campos, A. D. L. O., Villani, C., Davis, B., \& Takagi, M. (2018). Ending extreme poverty in rural areas-Sustaining livelihoods to leave no one behind.

Chamhuri Siwar dan Mohd Haflah Piei. (1988). Dasar dan Strategi Pembasmian Kemiskinan: Kumpulan Rencana Tentang Kemiskinan. Kuala Lumpur: Dewan Bahasa Dan Pustaka.

Conconi, Adriana y Viollaz, Mariana (2017) The Age of Perplexity: Rethinking the World we Knew. Poverty, Inequality and Development: Endogenous Vs. Exogenous Factors. Madrid, BBVA, OpenMind, Penguin Random House Grupo Editorial. Retrieved from https://www.bbvaopenmind.com/en/articles/poverty-inequality-and-development-a-discussionfrom-the-capability-approach-s-framework/

Damba, O. T., Abarike, M. A., Nabilse, C. K., \& Akudugu, M. A. (2019). URBAN POVERTY ANALYSIS IN TAMALE, GHANA. UDS International Journal of Development, 6(2), 79-96.

Deepa, N., Raj, P., Kai, S., Anne, R., \& Sarah, K.S. (1999). Voices of the poor: Can anyone hear us? New York, Oxford University Press.

Economic Planning Unit. (2020). Eleven Malaysia Plan 2016-2020. Retrieved from. https://www.epu.gov.my/sites/default/files/2020-02/Buku\%20RMKe-11.pdf

Economic Planning Unit. (2018). Mid Term Review Eleven Malaysia Plan 2016-2020. Retrieved from http://www.epu.gov.my/sites/default/files/2020-08/Mid Term\%20Review\%20of\% 2011th\%20Malaysia\%20Plan.pdf.

Fusco, A. (2003). On the definition and measurement of poverty: The contribution of multidimensional analysis. 3rd Conference on the Capability Approach: From Sustainable Development to Sustainable Freedom

Gopal, P. S. (2018). Poverty measurement revisited from a multidimensional perspective among Universiti Sains Malaysia's B40 poor students. Geografia-Malaysian Journal of Society and Space, 14(4).

Hijaz, S. T., \& Naqvi, S. R. (2006). Factors affecting students' performance: A case of private colleges in Bangladesh. Journal of sociology, 3(1), 44-45.

Iheonu, C., \& Urama, N. E. (2019). Addressing Poverty Challenges in Nigeria. Retrieved from https://media.africaportal.org/documents/Addressing_Poverty_Challenges_in_Nigeria_.pdf

Jabatan Perangkaan Malaysia (2020) LAPORAN SURVEI PENDAPATAN ISI RUMAH DAN KEMUDAHAN ASAS 2019. Jabatan Perangkaan Malaysia, Putrajaya, Malaysia. Jabatan Perangkaan Malaysia.

Jabatan Perangkaan Malaysia (2020). Laporan Survei Pendapatan Isi Rumah \& Kemudahan Asas 2019. Jabatan Perangkaan Malaysia, retrieved from https://www.dosm.gov.my/v1/index.php?r=column/cthemeByCat\&cat=120\&bul_id=TU00TmR hQ1N5TUxHVWN0T2VjbXJYZz09\&menu_id=amVoWU54UT10a21NWmdhMjFMMWcyZz 09

Le, H., Nguyen, C., \& Phung, T. (2015). Multidimensional poverty: evidence from Vietnam. Economics Bulletin, 35(4), 2820-2831.

Liu, Y., \& Xu, Y. (2016). A geographic identification of multidimensional poverty in rural China under the framework of sustainable livelihoods analysis. Applied Geography, 73, 62-76.

Laderchi, C. R. (2000). The monetary approach to poverty: A survey of concept and methods. QEH Paper Series 58.

Lutfun Nahar Lata (2020): To Whom Does the City Belong? Obstacles to Right to the City for the Urban Poor in Bangladesh, Journal of Contemporary Asia, DOI: $10.1080 / 00472336.2020 .1791934$

Muhammad Yunus. (2007) Creating a world without poverty: Social business and the future of capitalism. New York, Public Affairs.

Michail Moatsos (2020). Global Absolute Poverty Present and Past since 1820(Doctoral Dissertation, Utrecht University, Utrecht Netherlands). Retrieved from https://dspace.library.uu.nl/handle/1874/399449

Mohamed Saladin Abdul Rasool, Mohd Fauzi Mohd Harun, Ariffin Mohd Salleh dan Noraini Idris. (2011a). Poverty measurement in Malaysia: A survey of the literature. Akademika 81(1): 73-81 
Mohamed Saladin Abdul Rasool, Mohd Fauzi Mohd Harun, Ariffin Mohd Salleh dan Noraini Idris. (2011b). Poverty measurement in Malaysia zakat institutions: A theoretical survey. Jurnal Ekonomi Malaysia 45(2011): 123-129

Nadia, N., Fairuz, N., \& Rahana, A. (2011). The Multidimensional Poverty Index (MPI) and its application in Malaysia: A case study UiTM students, Shah Alam campus. Prosiding Perkem Vi, Jilid 1. 450-467.

Norzita Jamil \& Siti Hadijah Che Mat (2014). Realiti kemiskinan: Satu kajian teoritikal. Jurnal Ekonomi Malaysia, 48(1), 167-177.

Nor Ghani, M. (1984). Dimensi Kemiskinan dan Rancangan Pembasmian Kemiskinan. Siri Kumpulan Esei: Ekonomi Pembangunan. Amir Hussin Baharuddin. Kuala Lumpur: Dewan Bahasa dan Pustaka.

Nurul Izzah Anwar (2020). Kemiskinan multidimensi dalam era Covid-19.Retrieved 6 December 2020, from Sinar harian: https://www.sinarharian.com.my/article/83964/KHAS/Pendapat/Kemiskinan -multidimensi-dalam-era-Covid-19.

Parthiban, S.G. (2013). Urban poverty among Indians in Penang: A study on nonmaterial causes (PhD dissertation). Retrieved from University Sains Malaysia

Poverty, O., \& Human Development Initiative. (2013). Multidimensional poverty measures using the Alkire Foster method.

Radin Firdaus Radin Badaruddin, Khoo Suet Leng, Nor Malina Malek \& Maslina Mohammed Saed \& Parthiban S Gopal (2019). Wacana Multidimensi Dalam Perancangan dan Pembangunan Di Malaysia. Malaysia: Penerbit Universiti Pendidikan Sultan Idris.

Ravallion, M. (1998). Poverty Lines in Theory and Practice. LMS Working Paper, 133. The World Bank

Rohima, S., Suman, A., Manzilati, A., \& Ashar, K. (2013). Vicious Circle Analysis of Poverty and Entrepreneurship. Journal of Business and Management (IOSR-JBM), 7, 33-46.

Ragayah, H. M. Z. (2007). Understanding the formulation of the revised poverty line in Malaysia. Akademika, 70(1).

Siti Hadijah Che Mat. (2015). Kemiskinan Isu Pendapatan dan Program Pembasmian. Sintok, Kedah: UUM Press.

Santos, M. E., \& Alkire, S. (2011). Training material for producing national human development reports. MPI: Construction and analysis. Oxford: Oxford Poverty and Human Development Initiative.

Siti, H. C. M, \& Roslan, A. H. (2011). Jangka masa keluar daripada kepompong kemiskinan dan ketermiskinan: Kajian kes di Kedah Darul Aman, Malaysia. Interanational Journal of Management Studies, 18(2), 217-236.

Shifa, M., \& Leibbrandt, M. (2017, December). Urban poverty and inequality in Kenya. In Urban Forum (Vol. 28, No. 4, pp. 363-385). Springer Netherlands.

Amartya Sen (1987). Poverty and famine: An essay on entitlement and deprivation. London, Clarendon.

Sen, A.K. (1976). Poverty: An ordinal approach to measurement, Econometrica, 44, 219-231

Sulochana, N. (2007). Concepts, definitions and the measurement of poverty in Malaysia: Issues for concern. In Nambiar, S. (Eds.), Reassessing poverty in Malaysia (pp. 132-169). Kuala Lumpur, Wisdom House Publications.

Sen, A. (1985). Commodities and capabilities. Amsterdam, North-Holland.

Sydunnaher, S., Islam, K. S., \& Morshed, M. M. (2019). Spatiality of a multidimensional poverty index: a case study of Khulna City, Bangladesh. GeoJournal, 84(6), 1403-1416.

Sabina, A., \& Maria,. E. S. (2011). Training material for producing national human development reports: the Multidimensional Poverty Index (MPI).

Townsend, P. (1979) Poverty in the United Kingdom. Harmondsworth: Penguin

United Nations. (2016). Sustainable development goals report 2016. UN.

Unit Perancang Ekonomi (2018) ringkasan eksekutif kajian separuh penggal Rancangan malaysia ke 11 (rmk11). Retrieved from http://www.kabinet. gov.my/bkpp/pdf/Kajian_separuh_penggal_RMK11.pdf

World Bank. (2018). Poverty and Shared Prosperity 2018: Piecing Together the Poverty Puzzle. Washington, DC: World Bank. License: Creative Commons Attribu- tion CC BY 3.0 IGO 
Malaysian Journal of Social Sciences and Humanities (MJSSH), Volume 6, Issue 1, (page 40 - 51), 2021

DOI: https://doi.org/10.47405/mjssh.v6i1.608

Watson, I. I., \& Derrill, D. (2014). Poverty and Basic Needs. Encyclopedia of Food and Agricultural Ethics. Springer Netherlands, 1529-1535. 